\title{
Tomasz Masłyk*
}

\section{KAPITAŁ SPOŁECZNY W EUROPEJSKICH WELFARE STATES}

\begin{abstract}
Kryzys finansów publicznych w krajach europejskich sprawia, że idea państwa opiekuńczego narażona jest dzisiaj na szczególnie ostrą krytykę. Nie sprowadza się ona jedynie do akcentowania braku efektywności działania tych instytucji. Wskazuje się również negatywny wpływ instytucji welfare state na działanie trzeciego sektora - ograniczanie sfer aktywności obywatelskiej, a co za tym idzie, eliminowanie naturalnych źródeł dla generowania kapitału społecznego. Celem artykułu było nawiązanie do tego problemu i pokazanie stanu faktycznego - zasobności kapitału społecznego, pozostającego w dyspozycji obywateli reprezentujących pięć typów państw opiekuńczych: anglosaskiego, korporacyjnego, socjaldemokratycznego, śródziemnomorskiego i postkomunistycznego. Pomiar kapitału społecznego przeprowadzony został z uwzględnieniem jego trzech wymiarów: zaufania (indywidualnego i instytucjonalnego), aktywności obywatelskiej (kapitału spajającego i pomostowego) i satysfakcji z życia (indywidualnej i systemowej). Analiza empiryczna oparta została na danych pochodzących z badań zrealizowanych w 2010 roku w ramach Europejskiego Sondażu Społecznego.
\end{abstract}

Słowa kluczowe: kapitał społeczny, państwo opiekuńcze, zaufanie, aktywność obywatelska

\section{WPROWADZENIE}

Przyjęcie założenia, iż generowanie kapitału społecznego może być pochodną jakości porządku instytucjonalnego wydaje się szczególnie interesujące w kontekście obserwowanego wzrostu (czy też rozrostu) struktur państwowych (szczególnie instytucji państwa opiekuńczego) prowadzącego z jednej strony do upaństwowienia społeczeństwa (stateification) i z drugiej do uspołecznienia państwa (societalization) (Rogers 2001) Taki instytucjonalny kontekst zmienia optykę patrzenia na kapitał społeczny - wspólnoty i stowarzyszenia pozostaja w orbicie oddziaływania instytucji formalnych, których sposób zorganizowania i działania może mieć istotne znaczenie dla wytwarzania kapitału społecznego (Woolcock, Narayan 2000: 225-238). Z jednej strony rozrastająca się struktura biurokratyczna wraz z państwowymi agendami odpowiedzialnymi za rozwiązywanie problemów społecznych (którymi kiedyś zajmowali się sami obywatele) sprzyja kurczeniu się sfery publicznej i pogłębia

* AGH Akademia Górniczo-Hutnicza; tomaslyk@wp.pl 
kryzys finansów publicznych ${ }^{1}$. Coraz mniej jest obszarów pozostawionych działalności autonomicznych, społecznych organizacji i stowarzyszeń, będących fundamentem społeczeństwa obywatelskiego. Skutkuje to redukcją rezerwuarów, w których kapitał społeczny jest generowany i kumulowany. Z drugiej jednak strony głównym celem państwa opiekuńczego jest redukcja nierówności społecznych, co może powodować zwiększenie „sumy zasobów aktualnych i potencjalnych, które należą się jednostce lub grupie z tytułu posiadania trwałej, mniej lub bardziej zinstytucjonalizowanej sieci relacji, znajomości, uznania wzajemnego" (Bourdieu i Wacquant 2001: 104-105), czyli kapitału społecznego.

Biorąc pod uwagę te potencjalne sprzeczności, rodzi się pytanie o wielkość kapitału społecznego, pozostającego w dyspozycji obywateli reprezentujących odmienne porządki $\mathrm{w}$ europejskich welfare states.

Tematyka artykułu koncentruje się na próbie wykazania stanu faktycznego, a nie przyczyn potencjalnego zróżnicowania, chociaż ów związek przyczynowo-skutkowy daje się zaobserwować dzięki połączeniu analiz na poziomie jednostkowym (subiektywnych ocen nawiązujących do relacji interpersonalnych jako pierwotnego źródła kapitału społecznego) i poziomie instytucjonalnym (subiektywnych ocen jakości instytucji państwa). Celem artykułu jest wskazanie różnic w pięciu typach państw opiekuńczych (anglosaskiego, korporacyjnego, socjaldemokratycznego, śródziemnomorskiego i postkomunistycznego) w obrębie trzech składowych kapitału społecznego (zaufania, aktywności obywatelskiej i satysfakcji z życia). Aby wykazać potencjalne korelacje pomiędzy sferą działań indywidualnych i instytucjonalnych, każdy wymiar kapitału społecznego na tych dwóch płaszczyznach został dodatkowo poddany analizie:

- w przypadku zaufania zmierzono zależność pomiędzy zaufaniem interpersonalnym i instytucjonalnym,

- w odniesieniu do aktywności obywatelskiej wzięto pod uwagę kapitał (aktywność) spajający i kapitał (aktywność) pomostowy,

- w wymiarze satysfakcji przyjęto perspektywę indywidualną oraz perspektywę instytucjonalną.

\section{KONTEKST TEORETYCZNY - KONTROWERSJE WOKÓŁ KAPITAŁU SPOŁECZNEGO W PAŃSTWIE OPIEKUŃCZYM}

Sama koncepcja kapitału społecznego jest dzisiaj szeroko dyskutowana - również w odniesieniu do państwa opiekuńczego czy państwa dobrobytu. Z jednej strony podkreśla

\footnotetext{
Wymiernym wskaźnikiem tych procesów jest stopień fiskalizmu, który określa relację wielkości wydatków publicznych do wielkości produktu krajowego brutto (PKB). Jak podaje Eurostat, w roku 2010 łączne wydatki publiczne wszystkich 27 krajów Unii Europejskiej wyniosły 50,6\% ich PKB. Najwyższą proporcję odnotowano w Irlandii (66,8\%), najniższą w Bułgarii (38,1\%). W Polsce wydatki budżetowe stanowiły 45,4\% PKB (Eurostat 2011). Dane długookresowe sprzed ponad wieku (z roku 1880) pokazują, że wydatki publiczne w krajach dzisiejszej starej Unii (UE-15) stanowiły zaledwie 5-10\% PKB (Polarczyk: 2005: 109). Taka struktura budżetu ma zawiązek z rosnącym zadłużeniem państw. W trzecim kwartale 2011 roku dług publiczny w Unii Europejskiej (UE-27) stanowił 82,8\% jej PKB. Najbardziej zadłużonym krajem Unii była Grecja (159,1\% PKB), najniższy dług odnotowano w Estonii (6,1\%), natomiast dług Polski stanowił 56,3\% PKB (Eurostat 2012).
} 
się negatywny wpływ instytucji państwa opiekuńczego, które zastępują obywateli w działaniach na rzecz własnych rodzin i wspólnot lokalnych, co prowadzi do osłabiania więzi między nimi (Boje 1996: 22-25). W tym rozumieniu wzrost sfery instytucji państwowych i realizowanych przez nie opiekuńczych funkcji skutkuje zmniejszaniem obywatelskiej samoświadomości i aktywności, a w konsekwencji zanikaniem naturalnych źródeł kapitału społecznego. W społeczeństwach, w których ludzie chronieni są przez państwo „od kołyski po grób”, społeczeństwo obywatelskie z kluczowymi dlań normami wzajemności jest wypierane (Wolfe 1989: 142). Ten efekt wypierania (crowding out effect) często jest akcentowany w pracach badaczy kapitału społecznego i społeczeństwa obywatelskiego (Cohen, Arato 1993; van Oorschot, Arts 2005; van Oorschot, Arts, Gelissen 2006). Jak utrzymują inni, współczesne państwo opiekuńcze prowadzi także do erozji poczucia solidarności i w miejsce odpowiedzialności indywidualnej wprowadza odpowiedzialność państwa (de Swann 1988). Odpowiedzialność, której źródło trudno zlokalizować, nie sprzyja poczuciu sprawstwa, przez co zmniejsza się stopień zaangażowania w społeczne formy aktywności, prowadząc jednocześnie do spadku ich efektywności. Skuteczność i efektywność działań w obrębie danej wspólnoty zależą od doświadczenia jednostek i możliwości oparcia ich na regułach wzajemności, których trudno doszukiwać się w relacjach państwo-obywatel (Fukuyama 2000). To właśnie w rodzinie i grupach nieformalnych realizowana jest większość potrzeb społecznych (łącznie z wytwarzaniem kapitału społecznego) i to ich odpowiedzialność powinna być zwiększana przy jednoczesnym ograniczaniu roli państwa (Miller 2004: 49).

Z drugiej jednak strony analizy empiryczne w pewnych przypadkach podważają tę linię argumentacji. Przykład krajów skandynawskich pokazuje, że państwu opiekuńczemu może towarzyszyć znaczny zasób kapitału społecznego, pozostającego w dyspozycji obywateli (Rothstein, Stolle 2003), m.in. w postaci wysokiego stopnia zaangażowania w organizacjach o charakterze woluntarystycznym (Rothstein 2001). Państwo opiekuńcze pośredniczy w redystrybucji zasobów, a dzięki ich wykorzystaniu niweluje nierówności i pośrednio wpływa na zwiększenie poziomu uczestnictwa i zaangażowania obywateli w organizacjach i stowarzyszeniach (van Ingen i van der Meer 2011). Podkreśla się tutaj również, że w niektórych państwach opiekuńczych zakres świadczonej pomocy jest pozytywnie skorelowany z jakością życia (Hagfors, Kajanoja 2007). Powoduje to, iż w krajach skandynawskich można zarejestrować pozytywny związek między rozwojem państwa opiekuńczego a trzecim sektorem, zwłaszcza wtedy, kiedy instytucje państwa opiekuńczego alokują swoje zasoby w organizacjach społeczeństwa obywatelskiego, tym samym skłaniając je do działań społecznie odpowiedzialnych (Kuhnle, Alestalo 2000). Dowodzi się jednocześnie, że nie istnieje uniwersalny wzór państwa opiekuńczego, które w każdym przypadku w jednakowy sposób i z jednakowym skutkiem osiaga założone cele. W zależności od tego, w jaki sposób ,zaprojektowane” są instytucje państwa opiekuńczego i kogo dotyczą programy społeczne przez nie realizowane, mogą przyczyniać się one do wytwarzania kapitału społecznego (inwestowania w niego) lub też prowadzić do jego degradacji (Kumlin, Rothstein 2005: 6-7). 


\section{TYPY PAŃSTW OPIEKUŃCZYCH}

Według Gøsty Esping-Andersena można wyróżnić kilka typów² państw dobrobytu (opiekuńczych) w światowym porządku kapitalistycznym:

(...) przegląd różnic dzielących poszczególne kraje pod względem charakterystycznych dla nich układów praw socjalnych i systemów nierówności społecznych wytwarzanych przez instytucje państwa opiekuńczego prowadzi do wyodrębnienia odmiennych rozwiązań dotyczących struktury powiązań pomiędzy państwem, rynkiem i rodziną. Oznacza to, że rozmaite wersje państwa opiekuńczego nie są linearnie uporządkowane na jednej skali, lecz skupiają się w pewne charakterystyczne porządki (Esping-Andersen 2010: 44).

Pierwszy z trzech porządków obejmuje liberalne (anglosaxon liberal) państwa opiekuńcze, ,z charakterystycznymi dlań skromnymi, testowanymi dochodowo, uniwersalistycznymi systemami transferów socjalnych lub skromnymi systemami zabezpieczenia socjalnego. Świadczenia są przeznaczone dla ludzi o skromnych dochodach, zwykle robotników, których położenie w strukturze społecznej jest uzależnione od państwa" (ibidem). Porządek ten w Europie reprezentowany jest przez Wielką Brytanię i Irlandię. Państwo opiekuńcze o znamionach korporacyjnych (continental conservative) właściwe jest dla krajów takich jak Austria, Francja, Niemcy, Belgia, Holandia oraz Włochy (typ reprezentowany przez te państwa określany jest również jako „motywacyjny” lub „służebny”).

W tych krajach dziedzictwo korporatyzmu wspieranego przez państwo zostało udoskonalone tak, aby sprostać warunkom wyznaczanym przez nową ,poprzemysłową” strukturę społeczną. (...) Nacisk kładło się na utrzymanie zastanej struktury społecznej i różnic statusowych, prawa socjalne były zatem wiązane z położeniem klasowym i statusem (Esping-Andersen 2010: 45).

Inaczej mówiąc, systemy zasiłków i wsparcia socjalnego finansowane są w odniesieniu do wysokości płaconych składek odprowadzanych w okresie pracy. Państwa skandynawskie - Szwecja, Dania, Finlandia i Norwegia - mają socjaldemokratyczne (scandinavian social democratic) cechy państwa opiekuńczego (reżimy te nazywane są również ,instytucjonalno-redystrybucyjnymi”). W państwach tych:

(...) zasady uniwersalizmu i dekomodyfikacji [proces w którym „zdobycze socjalne” są niezależne od statusu rynkowego - przyp. autora] zostały rozszerzone również na klasy średnie. (...) Socjaldemokraci - odrzucając dualizm rynku i państwa, nie tolerując strukturalnego podziału między klasą robotniczą i klasą średnią - szukali takich rozwiązań, które mogłyby zapewnić równość świadczeń o wysokim standardzie, nie zaś równość w dostępie do świadczeń minimalnych” (ibidem).

Typologię opracowaną przez Gøstę Esping-Andersena można uzupełnić typem czwartym, południowoeuropejskim (Southern European), określanym również jako „śródziemnomorski” lub ,początkujący” czy też „elementarny” (budding), którego cechy są obecne w takich

2 Koncepcja Espinga-Andersena ,trzech reżimów kapitalizmu socjalnego” stanowi jedną z wielu propozycji typologii (zob. Szarfenberg 2009). 
państwach jak Grecja, Portugalia, Hiszpania, ale również Włochy ${ }^{3}$ (van Oorschot, Arts, Halman 2005: 36). To, co jest charakterystyczne dla tych krajów, to fakt, że idei opiekuńczości obecnej w zapisach ustawy zasadniczej nie towarzyszy silne osadzenie w instytucjonalnym, prawnym czy społecznym porządku. Ostatnim typem, który w ujęciu historycznym jest najmłodszy (chociaż mocno warunkowany historycznymi realiami), jest typ postkomunistyczny, reprezentowany przez kraje byłego bloku wschodniego. Przenikanie się w tym postkomunistycznym porządku cech właściwych dla różnych typów czyni z niego swoistą - jeśli odwołamy się do przykładu Polski - paternalistyczno-rynkową hybrydę (zob. Księżopolski 2004).

W każdym z wyróżnionych przez Gøstę Esping-Andersena porządków państwa opiekuńczego relacje pomiędzy sferą prywatną, rynkową i państwową charakteryzują się różnym rozłożeniem akcentów, skutkującym odmiennym sposobem prowadzenia polityki społecznej. Jest to widoczne nie tylko w dziedzinie fiskalizmu, stratyfikacji i porządku instytucjonalnego, ale przede wszystkim w sferze normatywnej. W przypadku rodziny jej rola w typie liberalnym i socjaldemokratycznym jest niewielka, natomiast duża w typie konserwatywnym i śródziemnomorskim. W odniesieniu do rynku niewielka regulacja jest właściwa dla porządku liberalnego, średnia dla socjaldemokratycznego i silna dla konserwatywnego. W porządku liberalnym welfare state ma charakter rezydualny, w typie konserwatywnym dominuje rozwinięty system ubezpieczeń społecznych, a typ socjaldemokratyczny opiera się na zasadzie uniwersalistycznej (Esping-Andersen 1999: 85-86). Porządek liberalny jest najbliższy realizmowi czy też empiryzmowi w myśleniu o systemie demokratycznym, natomiast typ konserwatywny reprezentuje myślenie racjonalne o demokracji, stając się jednocześnie emanacją projektu politycznego (Sartori 1998: 70-71).

\section{METODOLOGIA I ŚCIEŻKA ANALIZY}

Opierając się na zaprezentowanej typologii (z pominięciem kwestii przyczyn, które zadecydowały o dominacji danych typów w poszczególnych krajach europejskich), spróbuję zidentyfikować różnice zachodzące między nimi w wymiarze kapitału społecznego na podstawie danych pochodzących z Europejskiego Sondażu Społecznego (ESS 2010), zrealizowanego na przełomie roku 2010 i $2011^{4}$. Chociaż w pierwszej edycji badań wzięli udział respondenci z dwudziestu krajów Europy (w tym Izraela), do analizy włączone zostały kraje reprezentujące wyszczególnione wcześniej typy państw opiekuńczych:

- anglosaski: Wielka Brytania,

- korporacyjny: Belgia, Francja, Holandia, Niemcy,

3 Ponieważ omawiane porządki oparte są na typologii, opisywane państwa nie reprezentują typów „,czystych”. Zmiana przynależności do danego typu może wiązać się z właściwościami przyjętych wskaźników. Stąd obecność Włoch zarówno w typie konserwatywnym, jak i śródziemnomorskim.

4 Ze względu na ograniczoną objętość artykułu pominięta została bardziej szczegółowa charakterystyka wykorzystanego w analizie zbioru danych. Dokładny opis procedur zastosowanych podczas realizacji badań, obejmujący m.in. sposób realizacji, wielkość i metody doboru i ważenia próby, a także stosowany w badaniach kwestionariusz, znaleźć można na oficjalnej stronie Europejskiego Sondażu Społecznego pod adresem: http:// www.europeansocialsurvey.org/ 
- socjaldemokratyczny: Dania, Finlandia, Norwegia, Szwecja,

- śródziemnomorski: Hiszpania, Portugalia,

- postkomunistyczny: Bułgaria, Czechy, Estonia, Polska, Słowenia, Węgry.

Analiza porównawcza została przeprowadzona w trzech etapach. W pierwszym przedstawiono zależność pomiędzy zaufaniem interpersonalnym a zaufaniem instytucjonalnym. Zaufanie ma dla wytwarzania kapitału społecznego fundamentalne znaczenie. Jest ono nie tylko atrybutem jednostki, ale przede wszystkim zbiorowości czy też sieci społecznych, w których jednostka funkcjonuje. Musi stać się doświadczeniem uniwersalnym, ogólnospołecznym (czy też kulturowym), aby mogło stanowić podstawę dla działań przynoszących wspólnocie wymierne korzyści. W badaniach Europejskiego Sondażu Społecznego „pomiarowi” zaufania towarzyszył pomiar dwóch powiązanych z nim kwestii: wzajemności i uczciwości ${ }^{5}$, co stanowi operacyjne odniesienie dla teoretycznych założeń koncepcji kapitału społecznego (Putnam 2008: 226-249). Zaufanie instytucjonalne dla państw opiekuńczych ma szczególne znaczenie, zakłada bowiem istnienie ,legitymizacji legalnej”. Bez zaufania wobec instytucji stanowiących i egzekwujących prawo trudno spodziewać się legitymizacji dla istniejącego porządku systemowego ${ }^{6}$. W tym ujęciu zaufanie instytucjonalne można rozumieć jako składową zaufania systemowego, czyli zaufania wobec ,żywotności porządku społecznego, potencjału społeczeństwa, funkcjonalności ustroju politycznego i ekonomicznego i tak dalej” (Sztompka 2007: 109-110).

W drugim etapie porównana została aktywność obywatelska (stowarzyszeniowa), rozumiana jako uczestnictwo w organizacjach i stowarzyszeniach $\mathrm{z}$ aktywnością opartą na osobistych, niezinstytucjonalizowanych relacjach z innymi, która w tym wypadku sprowadzona została do pomiaru deklarowanej częstości spotkań towarzyskich ${ }^{7}$. Z jednej strony kapitał społeczny może być wytwarzany dzięki relacjom ,pomostowym”, łączącym daną wspólnotę i jej członków z podmiotami znajdującymi się na zewnątrz, z drugiej strony dzięki relacjom „spajającym”, które decydują o stosunkach zachodzących wewnątrz danej wspólnoty. Tylko wysoki poziom jednej i drugiej formy kapitału społecznego gwarantuje możliwość osiagania indywidualnych i wspólnotowych korzyści, szczególnie w wymiarze ekonomicznym (Woolcock, Narayan 2000: 231-232).

\footnotetext{
5 W badaniach ESS pytania o te trzy kwestie formułowane są w następujący sposób: w przypadku zaufania - „Czy, ogólnie biorąc, większości ludzi można ufać, czy też, że w kontaktach z ludźmi ostrożności nigdy za wiele?”. W przypadku uczciwości - „Czy gdyby nadarzyła się okazja, większość ludzi starałaby się Pana/Panią wykorzystać, czy też starałaby się postępować uczciwie?”. Natomiast pytanie o wzajemność brzmi: „Czy ludzie przede wszystkim starają się służyć pomocą innym, czy też przede wszystkim dbają o własny interes?”. Odpowiedzi umieszczane są na 11-stopniowej skali, której biegun „,0" wyraża przekonanie o braku zaufania, uczciwości i wzajemności wśród ludzi, natomiast biegun „10” przekonanie o obecności tych norm w życiu społecznym.

6 Zaufanie instytucjonalne zostało określone na podstawie ocen zaufania wobec parlamentu, systemu prawnego, policji, polityków i partii politycznych, których dokonywano z wykorzystaniem podobnej jak w przypadku zaufania interpersonalnego, 11-stopniowej skali.

7 Za wskaźnik aktywności stowarzyszeniowej przyjęto deklarację o działalności „,W partii politycznej lub organizacji podejmującej działalność społeczną lub polityczną” lub „działalność w innego rodzaju organizacji lub stowarzyszeniu”. Wskaźnikiem dla aktywności niesformalizowanej było pytanie o „częstość spotkań w celach towarzyskich z przyjaciółmi, znajomymi, krewnymi lub kolegami z pracy”.
} 
W trzecim etapie analizowano zależność pomiędzy zadowoleniem z porządku instytucjonalnego i ogólnym zadowoleniem z życia ${ }^{8}$. W przypadku państwa opiekuńczego ma to szczególne znaczenie, ponieważ można założyć, że ogólnie rozumiana życiowa satysfakcja warunkowana jest ,jakością” tego życia, a w porządku welfare state za ową jakość odpowiedzialne są m.in. instytucje państwa opiekuńczego. Co więcej, ogólnie rozumiana satysfakcja z życia (w wymiarze indywidualnym i systemowym) może wzmacniać gotowość przystępowania do organizacji społecznych i angażowania się w działania wspólnotowe (Scheufele, Shah 2000: 114).

Opierając się na danych z ESS 2010, obliczenia statystyczne przeprowadzono z uwzględnieniem odpowiedzi respondentów z siedemnastu krajów reprezentujących analizowane porządki welfare states, co dało łącznie sumę 32560 badanych osób. Ważenie próby oparto na sugerowanej przez realizatorów badań wadze uwzględniającej wielkość populacji w danym kraju powyżej piętnastego roku życia (granica piętnastu lat wyznaczała najmłodszych respondentów biorących udział w badaniu). Dla każdej zmiennej uwzględnionej w analizie sprawdzono wielkość braków danych, które były stosunkowo nieliczne (od 0,1\% do 4,1\%) i w głównej mierze wiązały się z odpowiedzią „nie wiem”. Ponieważ proporcje braków danych w odniesieniu do kilku zmiennych demograficzno-społecznych, takich jak: płeć, wiek, wykształcenie, dochód czy miejsce zamieszkania (które to zmienne uznano za kluczowe dla potencjalnego różnicowania opinii na temat wielkości kapitału społecznego) były zbieżne z proporcjami dla całej próby, zdecydowano się wykluczyć je z analizy.

\section{WYNIKI}

\subsection{ZAUFANIE INTERPERSONALNE I INSTYTUCJONALNE}

Zarówno zaufanie w wymiarze interpersonalnym, jak i instytucjonalnym zoperacjonalizowano na podstawie miar złożonych w postaci indeksów. Okazuje się bowiem, że oceny zaufania, uczciwości i wzajemności są ze sobą skorelowane (o czym świadczy przyzwoicie wysoka rzetelność mierzona współczynnikiem alpha Cronbacha) w przypadku każdego z analizowanych porządków (od 0,638 dla porządku anglosaskiego do 0,754 dla porządku postkomunistycznego). Przekonaniu o uczciwości innych towarzyszy podobna ocena ich uczciwości i skłonności do przyjmowania postaw cechowanych wzajemnością (solidarnością). Podobna sytuacja miała miejsce w ocenach porządku instytucjonalnego. W tym wypadku wartości określające rzetelność indeksu zbudowanego na podstawie ocen poszczególnych, instytucjonalnych aspektów, wahały się od 0,850 dla porządku śródziemnomorskiego do 0,887 dla porządku anglosaskiego. Oznacza to, że zaufanie wobec polityków i partii politycznych idzie w parze z zaufaniem do

\footnotetext{
8 Zadowolenie w wymiarze instytucjonalnym mierzone było na podstawie ocen: stanu gospodarki, sposobu działania rządu, funkcjonowania demokracji, stanu kształcenia, edukacji i stanu służby zdrowia i dostępnych usług medycznych z wykorzystaniem 11-punktowej skali, na której biegun oznaczony wartością „,” opisany został jako „zupełnie niezadowolony” (lub „,bardzo zły”), natomiast biegun przeciwległy (wartość „10”) jako „całkowicie zadowolony” (lub „,bardzo dobry”). Pomiaru zadowolenia z obecnego życia dokonano na podstawie takiej samej, 11-punktowej skali.
} 
parlamentaryzmu i stanowionego przez parlament prawa, a także do tych, którzy mają stać na straży tego porządku, czyli policji. Indeksy dla obu wymiarów zostały przygotowane jako iloraz sumy wartości ocen każdego aspektu i liczby ocenianych elementów (co umożliwiło sprowadzenie wartości wynikowej do wartości z przedziału wyjściowego 0-10).

Średnia wartość punktowa w przypadku zgeneralizowanego zaufania interpersonalnego dla wszystkich respondentów z analizowanych krajów wyniosła 5,14 (odpowiednio 4,87 dla zaufania, 5,65 dla uczciwości i 5,14 dla wzajemności). Dla zaufania instytucjonalnego wartość średnia indeksu dla ogółu badanych była równa 4,45 (odpowiednio: 4,17 dla parlamentu, 5,0 dla systemu prawnego, 6,07 dla policji, 3,28 dla polityków i 3,27 dla partii politycznych).

Najwyższym stopniem zaufania - w jego interpersonalnym i instytucjonalnym wymiarze - charakteryzują się Skandynawowie. W ich przypadku wartość dla jednej i dla drugiej postaci zaufania dominuje nad wartościami uzyskanymi w państwach z innych analizowanych układów. Co więcej, wśród państw reprezentujących porządek socjaldemokratyczny zaznacza się największa zbieżność ocen, czego nie można powiedzieć o ocenach w innych układach. Gdyby jednak spróbować utworzyć ranking zaufania (na podstawie uśrednionych wartości), to na drugim miejscu znalazłyby się państwa z porządku korporacyjnego wespół z Wielką Brytanią reprezentującą porządek anglosaski, a następnie państwa z układu śródziemnomorskiego (w którym jednak Hiszpania zyskuje znaczną przewagę nad Portugalią) i porządku postkomunistycznego (w którym zaznacza się przewaga in plus Estonii) ${ }^{9}$ (rys. 1).

Wnioski na podstawie analizy o tak wysokim stopniu ogólności muszą być formułowane ostrożnie. Każdy z respondentów w swoich ocenach bez wątpienia kierował się własnym, indywidualnym bilansem zaufania, który należy traktować jako wypadkową oddziaływania wielu rozmaitych czynników - doświadczeń osobistych, własnych przekonań czy wpływu środków masowego przekazu. W każdym z analizowanych krajów zgeneralizowane zaufanie interpersonalne było wyżej oceniane niż zgeneralizowane zaufanie instytucjonalne. Okazuje się jednak, że relatywnie niższa ocena zaufania w wymiarze instytucjonalnym jest konsekwencją przede wszystkim braku zaufania wobec polityków i partii politycznych. W przypadku polityków i partii politycznych jedynie w Danii, Szwecji i Holandii średnia wartość oceny zaufania przekracza lub jest równa wartości środkowej indeksu $(5,0)$, która wyznacza punkt graniczny pomiędzy brakiem zaufania i ufnością. Nieco wyższą ocenę - we wszystkich krajach - wystawiono parlamentowi, a następnie systemowi prawnemu.

9 Test różnic wartości średnich na obu indeksach wśród państw tworzących dane porządki welfare states potwierdza te spostrzeżenia (zastosowano tutaj wielokrotne porównania średnich wartości, wykorzystując nieparametryczny test Manna-Whitneya dla $\mathrm{p}<0,001$; testy post hoc ANOVY wykazały identyczne zależności). Kraje z porządku socjaldemokraktycznego zyskują istotną przewagę nad wszystkimi innymi typami państw na obu wymiarach. Wielka Brytania ustępuje istotnie typowi korporacyjnemu pod względem zaufania instytucjonalnego, ale wyprzedza go pod względem zaufania interpersonalnego. Jednocześnie zyskała istotną przewagę nad typem śródziemnomorskim i postkomunistycznym. Wreszcie porządek śródziemnomorski zyskuje na obu indeksach istotną przewage jedynie nad układem postkomunistycznym, ale ustępuje porządkowi korporacyjnemu. Zależności te należy interpretować ostrożnie, biorąc pod uwagę fakt, że poszczególne typy państw reprezentowane były przez respondentów z krajów, które nierzadko znacznie się od siebie różnią (mimo zaklasyfikowania ich do danego porządku). Istotne znaczenie dla uzyskanych ocen miały także zróżnicowane liczebności respondentów - większą wagę dla wypadkowej oceny na określonym wymiarze w przypadku danego typu państw zyskiwały oceny respondentów pochodzących z krajów liczniejszych). 


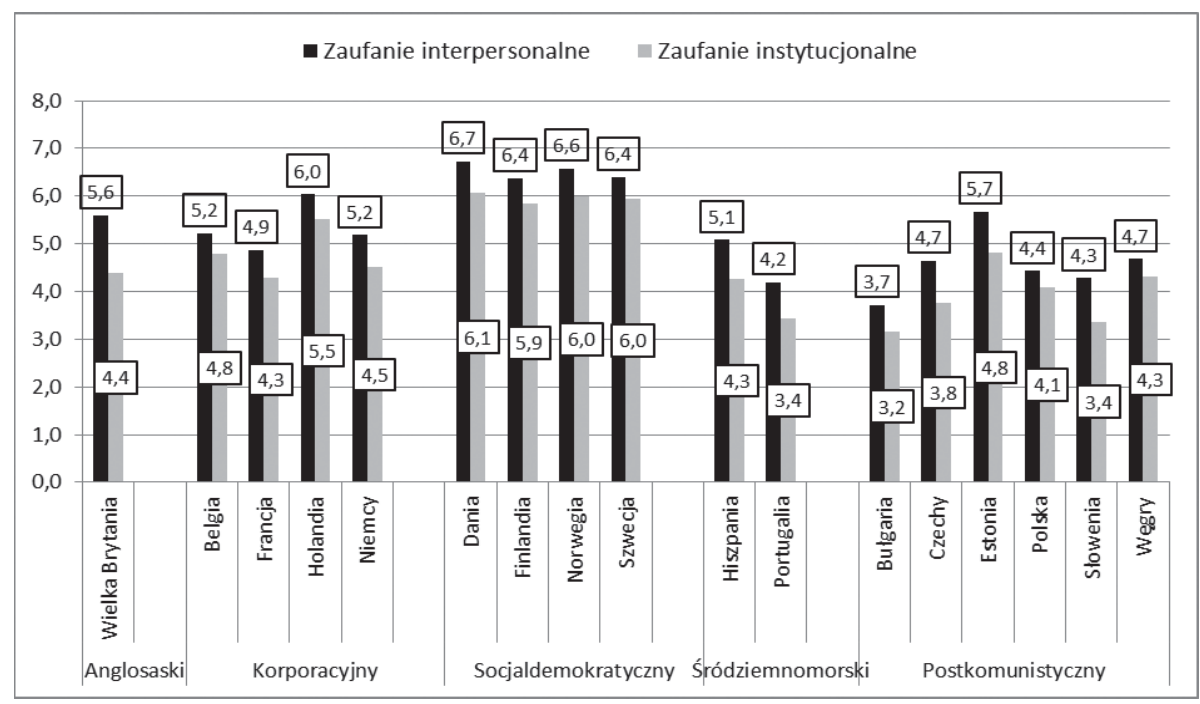

Rys. 1. Rozkład zaufania interpersonalnego i instytucjonalnego wśród pięciu porządków welfare state (wartości średnie).

Źródło: opracowanie własne na podstawie ESS 2010

W ocenie zaufania do parlamentu jedynie w Danii, Finlandii, Holandii Norwegii i Szwecji opinie pozytywne przeważają nad negatywnymi, a w przypadku systemu prawnego sytuacja ta dotyczy tych samych pięciu krajów oraz dodatkowo Niemiec, Estonii i Wielkiej Brytanii. Co ciekawe, zaufanie do policji we wszystkich siedemnastu krajach jest wyższe od średniej wartości dla zgeneralizowanego zaufania interpersonalnego. Na wysokość oceny tak rozumianego zaufania wpływa przede wszystkim przekonanie o uczciwości innych - wśród respondentów z siedemnastu badanych krajów w przypadku szesnastu ocena ta była najwyższa w porównaniu z ocenami zaufania i wzajemności. Jedynie Brytyjczycy najwyżej ocenili wzajemność, która szczególnie w porządku anglosaskim można traktować jako ważną z punktu widzenia własnego interesu (zob. Putnam 2008: 227). Analizując ogólne oceny dotyczące zaufania, można zauważyć, że zaufanie interpersonalne jest mocno skorelowane z zaufaniem instytucjonalnym ( $\mathrm{r}$ Pearsona $=0,925$ dla $\mathrm{p}<0,01$ ), chociaż jedynie w porządku socjaldemokratycznym wzór ten jest spójny - wszystkie państwa w tym układzie charakteryzuje wyższy stopień obu form zaufania w porównaniu z innymi państwami (rys. 2).

Chociaż trudno zakładać istnienie deterministycznej zależności przyczynowo-skutkowej pomiędzy zaufaniem interpersonalnym i zaufaniem instytucjonalnym, to jednak przedstawione relacje skłaniają do sformułowania mniej radykalnego wniosku o istnieniu takiej przyczynowej zależności. Tam, gdzie porządek instytucjonalny oceniany jest wyżej (cieszy się większym zaufaniem obywateli), tam również wyżej ocenia się jakość relacji międzyludzkich. 


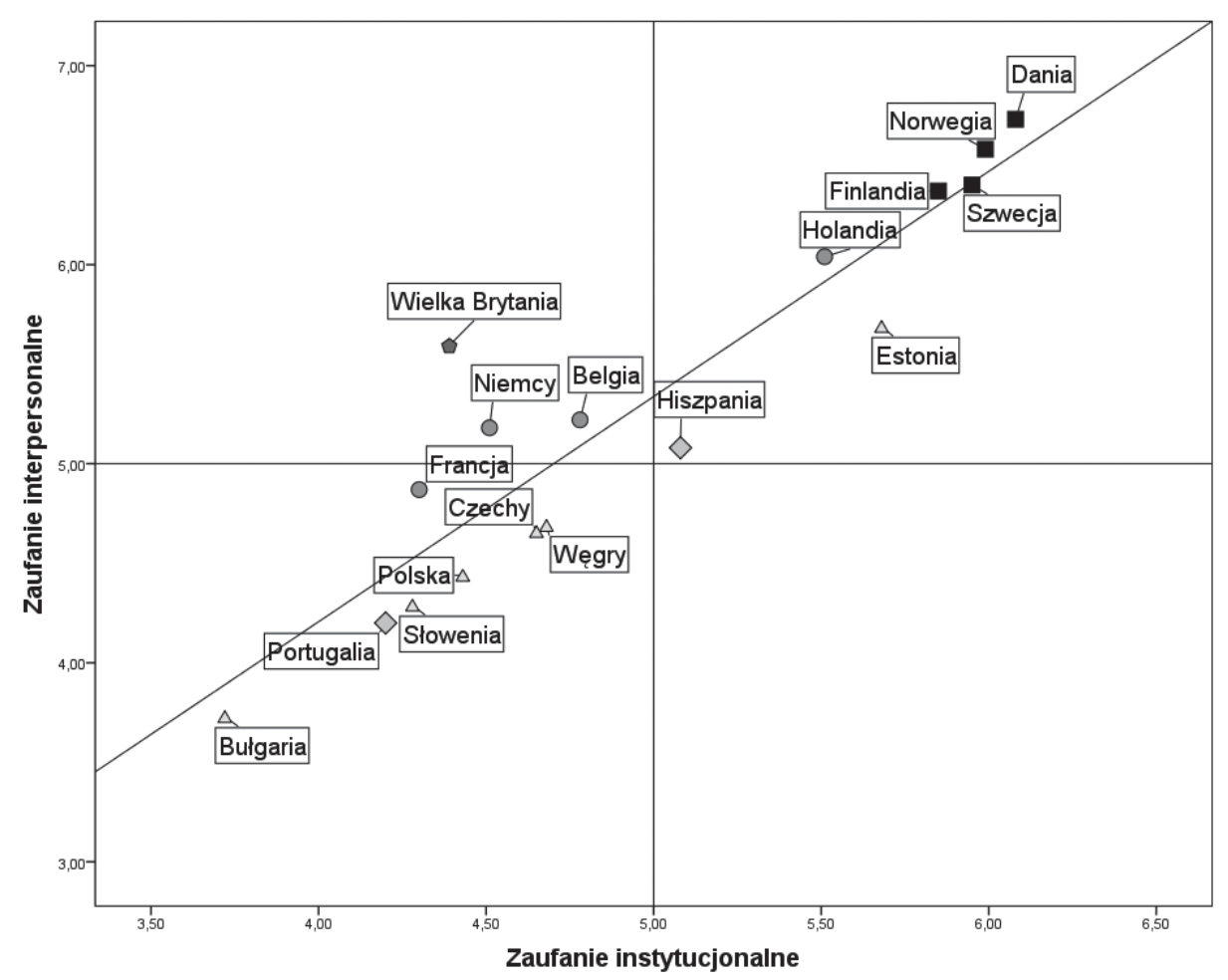

Rys. 2. Zależność pomiędzy zaufaniem interpersonalnym i zaufaniem instytucjonalnym.

Źródło: opracowanie własne na podstawie ESS 2010

\subsection{AKTYWNOŚĆ POMOSTOWA I SPAJAJĄCA}

Sieci społeczne stanowią przestrzeń, w której dochodzi do generowania kapitału społecznego. Podobnie jak kapitał fizyczny czy kapitał ludzki, może on stanowić wartość zarówno dla jednostek, jak i całych zbiorowości. Tak jak i inne formy kapitału, także kapitał społeczny można ,inwestować” w taki sposób, że nierzadko przyczynia się on do wzrostu dobrobytu danej wspólnoty w stopniu wyższym niż dobra materialne, wiążąc ze sobą poczucie szczęścia jednostek mocniej, niż czyni to kapitał finansowy. Szczęście - jak pokazują badania na całym świecie - jest silnie warunkowane rozległością i głębokością społecznych więzi (Putnam, Goss 2004: 8). Dla określenia stopnia zaangażowania obywatelskiego/społecznego w analizowanych krajach wyróżnione zostały dwa wymiary: aktywność „pomostowa”, rozumiana jako działalność w układach sformalizowanych - partiach politycznych, organizacjach i stowarzyszeniach, i aktywność ,,spajająca”, mierzona częstotliwością spotkań towarzyskich, przy 
czym za punkt odniesienia dla układu aktywny-bierny przyjęto częstość spotkań co najmniej raz w tygodniu (co w założeniu świadczy o ich względnej regularności).

Ogólnie dwóch na trzech Europejczyków (z analizowanych siedemnastu krajów) spotyka się towarzysko przynajmniej raz w tygodniu $(63,6 \%)$, natomiast $40,2 \% \mathrm{z}$ nich w chwili badania zadeklarowało aktywność o charakterze obywatelskim, wskazując członkostwo w którymś z typów organizacji.

W przypadku aktywności stowarzyszeniowej (pomostowej) dla porównywanych porządków welfare state widoczna jest podobna zależność jak w przypadku zaufania. Najaktywniejsi w tym wymiarze są mieszkańcy krajów skandynawskich - i stopień tej aktywności jest większy niż w jakimkolwiek innym europejskim kraju. Niższą aktywnością obywatelską charakteryzują się kraje należące do porządku korporacyjnego. W układzie śródziemnomorskim Hiszpania zyskuje zdecydowaną przewagę nad Portugalią, a w krajach postkomunistycznych w każdym przypadku zaznacza się niski poziom aktywności, chociaż w Czechach, Polsce czy Estonii poziom aktywności jest nieco wyższy niż w Wielkiej Brytanii. Aktywność spajająca nie układa się już w taki regularny wzór (pewne znaczenie ma tutaj charakter tego wskaźnika i przyjęcie arbitralnych założeń dla dychotomii aktywny-bierny). Wysoka częstotliwość spotkań charakteryzuje kraje z porządku śródziemnomorskiego i socjaldemokratycznego, nieco niższa anglosaskiego i korporacyjnego, a zdecydowanie najniższa z postkomunistycznego (rys. 3).

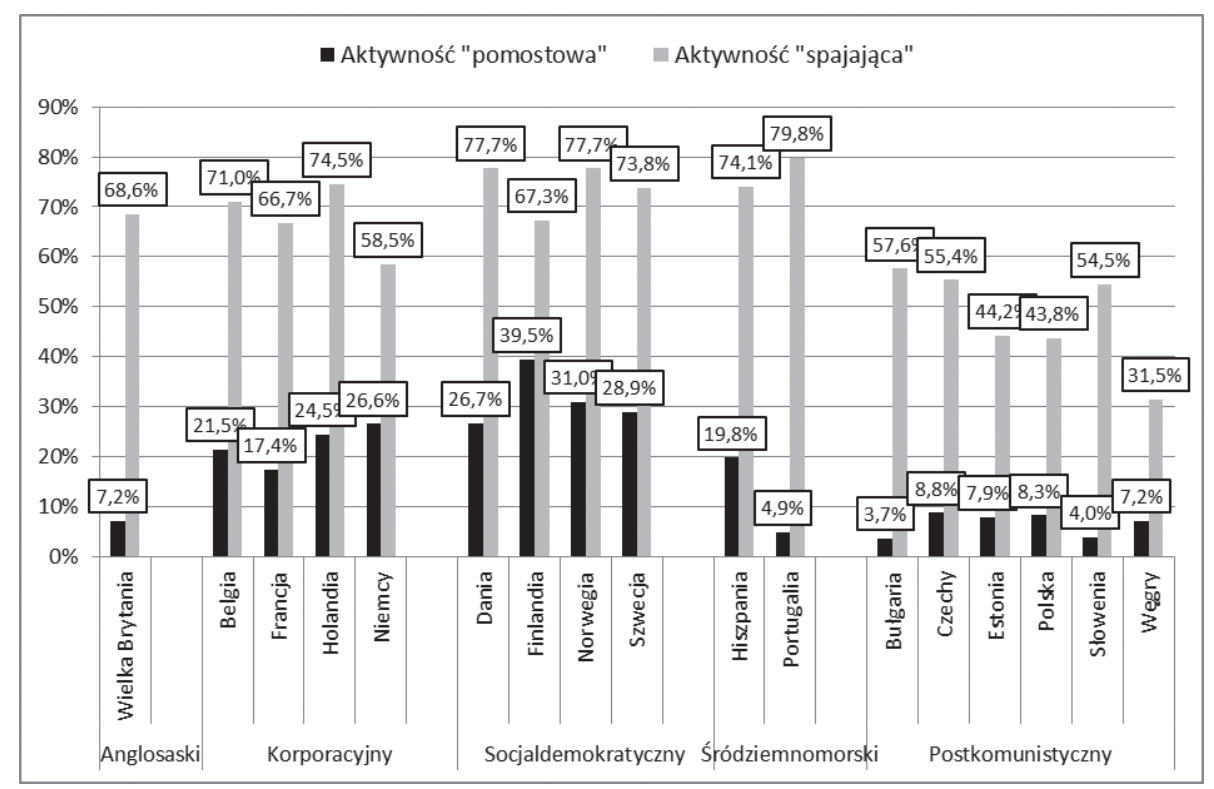

Rys. 3. Stopień aktywności pomostowej i spajającej wśród pięciu porządków welfare state (wartości procentowe).

Źródło: opracowanie własne na podstawie ESS 2010 
Pomimo dostrzeganych nieregularności zależność pomiędzy stopniem aktywności obywatelskiej (pomostowej) i spajającej jest istotna, chociaż niższa niż w adekwatnym układzie zaufania (r Pearsona $=0,526$ dla $\mathrm{p}<0,05$ ) (rys. 4).

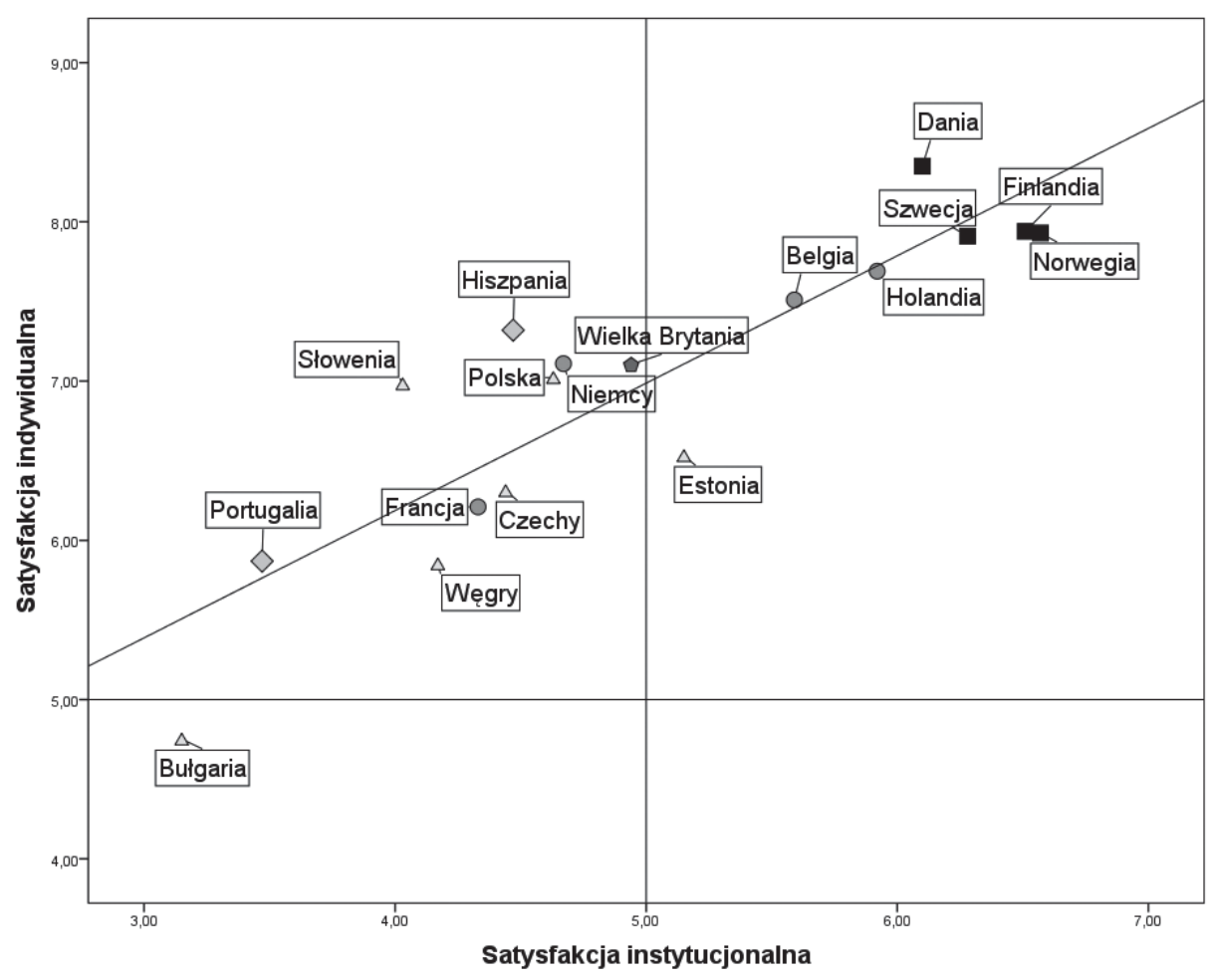

Rys. 4. Zależność pomiędzy aktywnością pomostową a spajającą.

Źródło: opracowanie własne na podstawie ESS 2010

Im wyższy stopień zaangażowania stowarzyszeniowego, tym na ogół również większa częstotliwość kontaktów towarzyskich. Także tutaj trudno jednoznacznie orzec, która forma aktywności jest determinująca względem innych, ale trafny wydaje się wniosek o ich powiązaniach. Spotkania towarzyskie mogą owocować zaangażowaniem w działalność społeczną, ta zaś może skutkować wyższą częstotliwością spotkań na gruncie nieformalnym. Także i tutaj można zatem mówić o kumulatywnym charakterze kapitału społecznego. 


\subsection{SATYSFAKCJA INDYWIDUALNA I INSTYTUCJONALNA}

Zadowolenie z życia jest na tyle złożonym zagadnieniem, iż trudno skonstruować model, który mógłby uwzględnić wszystkie zmienne wpływające na odczuwany poziom życiowej satysfakcji. Duże znaczenie dla oceny własnego życia mają te jego dziedziny, które są człowiekowi najbliższe - życie rodzinne, status socjoekonomiczny, osiagnięcia połączone z określonym stylem życia czy sposób (i jakość) organizacji życia społecznego w najbliższym otoczeniu. Istotne znaczenie ma również ogólnie rozumiany poziom życia będący wynikiem oddziaływania zmiennych makrospołecznych czy makroekonomicznych (zob. Masłyk 2010). Jakość życia zależy przede wszystkim od wysiłków indywidualnych czy wspólnotowych (w których istotną rolę odgrywa kapitał społeczny), ale decydować o niej może również układ czynników instytucjonalnych, co jest szczególnie istotne w państwach opiekuńczych. W tym rozumieniu warto przyjrzeć się rozkładowi satysfakcji instytucjonalnej i indywidualnej wśród reprezentantów analizowanych porządków welfare state.

Oceny tworzące indeks satysfakcji instytucjonalnej są ze sobą skorelowane we wszystkich analizowanych krajach (dokonywano w nich spójnych ocen gospodarki, rządu, demokracji, edukacji i służby zdrowia). Na ogół najwyżej oceniano służbę zdrowia (średnia ocena równa 5,5) lub system edukacji $(5,3)$, dalej demokrację $(4,96)$, gospodarkę $(4,09)$ i rząd $(3,83)$.

O adekwatności tych sądów w powiązaniu z rzeczywistą sytuacją w danym obszarze życia społecznego może świadczyć wysoka korelacja pomiędzy ocenami sytuacji gospodarczej w poszczególnych krajach a wartościami wskaźnika konkurencyjności GCI (Global Competetiveness Index) (zob. Schwab 2011: 15) ich gospodarek (r Pearsona $=0,759$ dla $\mathrm{p}<0,01$ ). Kondycja gospodarcza danego kraju idzie również w parze z jakością życia, o czym świadczy silna zależność ( $\mathrm{r}$ Pearsona $=0,788$ dla $\mathrm{p}<0,01$ ) pomiędzy poziomem rozwoju gospodarczego (wskaźnik GCI) i społecznego, wyrażonego wartością wskaźnika rozwoju społecznego HDI (Human Development Index) (zob. Human Development Report 2010). Zależności te widać również w ocenach respondentów z poszczególnych krajów. Podobnie jak wcześniej, daje się zauważyć relatywnie najwyższy poziom satysfakcji instytucjonalnej i indywidualnej wśród mieszkańców krajów skandynawskich i również tutaj są to oceny bardzo do siebie zbliżone. Na drugim miejscu pod względem poziomu satysfakcji są kraje z porządku korporacyjnego (chociaż Belgowie i Holendrzy uzyskali na obu wymiarach wyższe oceny od Niemców i Francuzów), następnie Brytyjczycy, których oceny zbliżone są do ocen Hiszpanów, na końcu kraje postkomunistyczne, z których większość (poza Bułgarią) stoi w rankingu satysfakcji wyżej od Portugaliii ${ }^{10}$ (wykres 5).

10 Test różnic wartości średnich na obu wymiarach dla pięciu analizowanych porządków pozwolił zweryfikować te sądy (tak jak poprzednio przeprowadzono porównania wielokrotne na podstawie nieparametrycznego testu Manna-Whitneya dla $\mathrm{p}<0,001$ ). Podobnie do ocen na obu indeksach zaufania, również w przypadku satysfakcji (indywidualnej i instytucjonalnej) istotną statystycznie przewagę nad wszystkimi innymi porządkami zyskali respondenci reprezentujący układ socjaldemokratyczny. Wielka Brytania z porządku anglosaskiego wyprzedza na obu indeksach przedstawicieli z typu korporacyjnego i postkomunistycznego, a na indeksie satysfakcji instytucjonalnej również kraje śródziemnomorskie (na indeksie satysfakcji indywidualnej nie odnotowano istotnych różnic). W porządku korporacyjnym w porównaniu z typem śródziemnomorskim uzyskano istotnie wyższe wskazania na indeksie satysfakcji instytucjonalnej, ale także istotnie niższe na indeksie satysfakcji interpersonalnej. Typ korporacyjny zyskał istotną przewagę nad typem postkomunistycznym na obu wymiarach, w krajach porządku postkomunistycznego w porównaniu z typem śródziemnomorskim nie ujawniły się istotne różnice w wymiarze satysfakcji instytucjonalnej, ale ten drugi typ zyskał istotną przewagę w przypadku satysfakcji indywidualnej. 


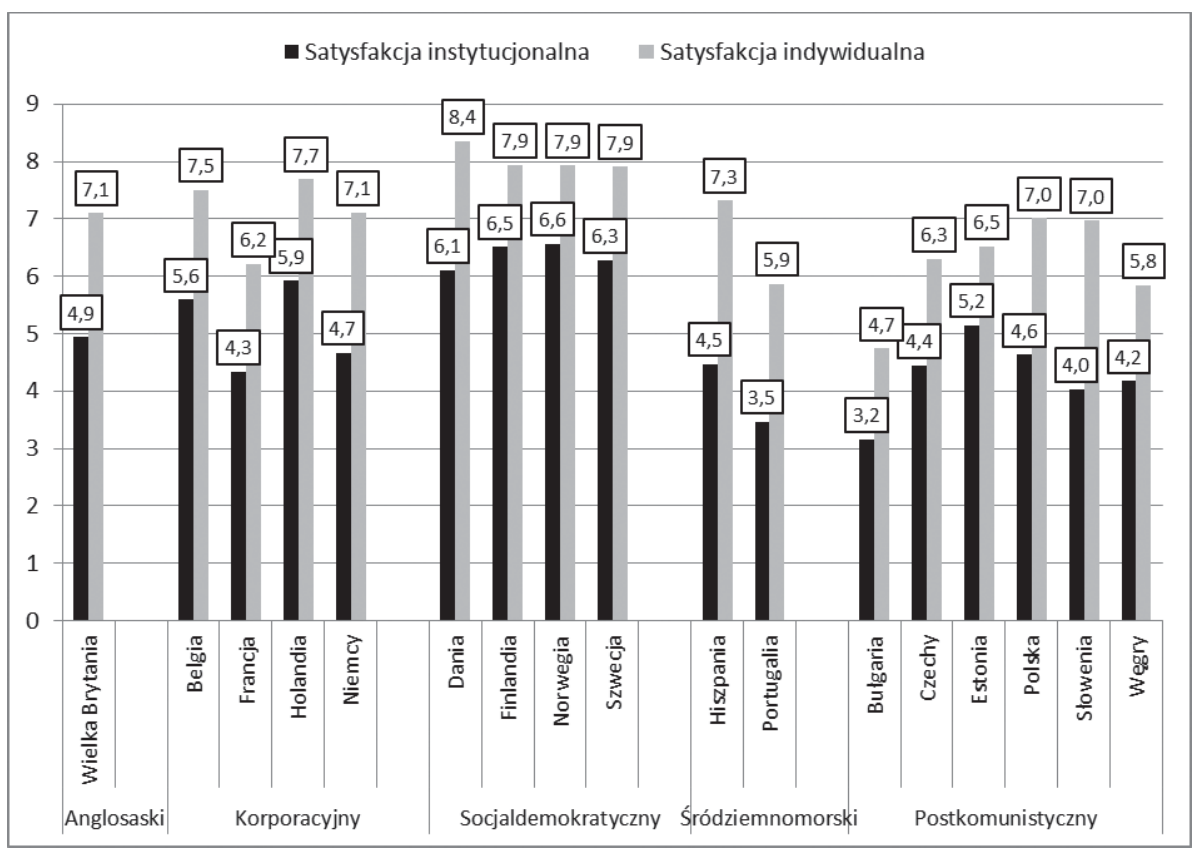

Rys. 5. Poziom satysfakcji instytucjonalnej i indywidualnej wśród pięciu porządków welfare states (wartości średnie).

Źródło: opracowanie własne na podstawie ESS 2010

Także i w tym układzie zmiennych poziom satysfakcji instytucjonalnej jest silnie skorelowany z poziomem satysfakcji indywidualnej ( $\mathrm{r}$ Pearsona $=0,884$ dla $\mathrm{p}<0,01$ ). Wyższa ocena stopnia zadowolenia z funkcjonowania porządku instytucjonalno-gospodarczego niesie ze sobą lepszą ocenę życia jako takiego (wykres 6).

Na koniec warto przyjrzeć się zależnościom pomiędzy wszystkimi trzema elementami kapitału społecznego wśród obywateli analizowanych porządków welfare states. O korelacjach pomiędzy nimi świadczą wyniki regresji liniowej - jeśli w modelu jako zmienna zależna zostanie wprowadzone zaufanie interpersonalne, a jako zmienne niezależne zaufanie instytucjonalne, aktywność pomostowa, aktywność spajająca ${ }^{11}$ oraz satysfakcja indywidualna i satysfakcja instytucjonalna, to uwidacznia się wpływ każdej z tych zmiennych niezależnych na zmienną zależną z osobna (przy kontroli wpływu pozostałych zmiennych) (tab.1).

11 Zmienne aktywność pomostowa i aktywność spajająca zostały wprowadzone do modelu jako zmienne binarne. W przypadku pierwszej zmiennej wartość 1 oznaczała członkostwo w organizacjach lub stowarzyszeniach, w odniesieniu do drugiej zmiennej wartość 1 oznaczała częstotliwość spotkań przynajmniej jeden raz w tygodniu. 


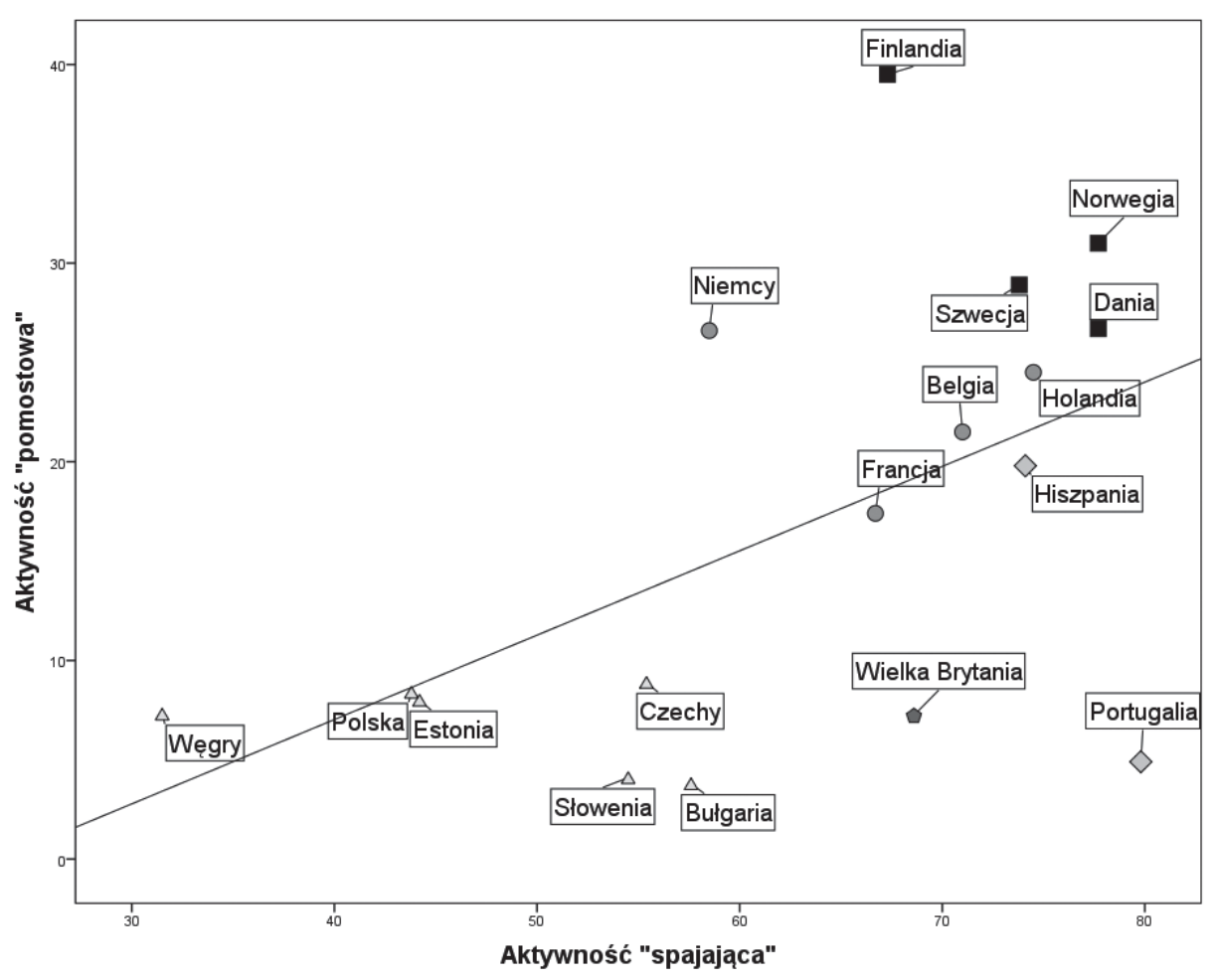

Rys. 6. Zależność pomiędzy satysfakcją instytucjonalną i satysfakcją indywidualną.

Źródło: opracowanie własne na podstawie ESS 2010

\section{Tabela 1}

Zależność pomiędzy zaufaniem interpersonalnym a pozostałymi elementami kapitału społecznego (wartości współczynników regresji liniowej)

\begin{tabular}{|l|c|}
\hline \multicolumn{1}{|c|}{ Zmienna } & Standaryzowany wspólczynnik beta \\
\hline Zaufanie instytucjonalne & $0,27^{*}$ \\
\hline Aktywność pomostowa & $0,17^{*}$ \\
\hline Aktywność spajająca & $0,14^{*}$ \\
\hline Satysfakcja indywidualna & $0,07^{*}$ \\
\hline Satysfakcja instytucjonalna & $0,04^{*}$ \\
\hline
\end{tabular}

${ }^{*}$ dla $\mathrm{p}<0,001$

Źródło: opracowanie własne na podstawie ESS 2010 
Najsilniej na zaufanie interpersonalne wpływa zaufanie instytucjonalne, co nie powinno zaskakiwać. W przestrzeni publicznej i społecznej, w której coraz większym stopniu swoją obecność zaznaczają instytucje formalne, zaufanie interpersonalne staje się pochodną zaufania kształtowanego na styku obywatel-państwo. Na zaufanie wpływają również dwie formy aktywności - bardziej ufają innym ci, którzy angażują się zarówno w życie towarzyskie, jak i organizacyjne. Najmniejszy, chociaż również istotny wpływ na poziom zaufania interpersonalnego ujawnia się w przypadku dwóch wymiarów satysfakcji - indywidualnej i instytucjonalnej. Także i tutaj można dostrzec, że zaufanie jest pochodną zadowolenia zarówno z własnego życia, jak i satysfakcji z funkcjonowania państwa w kluczowych dla życia społecznego obszarach.

\section{PODSUMOWANIE}

Wnioski płynące z przeprowadzonej analizy są dwojakiego rodzaju. Po pierwsze kapitał społeczny ma kumulatywny charakter: zaufanie interpersonalne jest powiązane z zaufaniem instytucjonalnym, aktywności stowarzyszeniowej wtóruje aktywność towarzyska, a satysfakcję indywidualną określa poziom satysfakcji instytucjonalnej. Świadczą o tym wysokie wartości współczynników korelacji pomiędzy wartościami analizowanych wymiarów kapitału społecznego. Przykłady diagnozowanych porządków welfare states pokazują, że dla jakości i zasobności kapitału społecznego niezbędne jest kooperatywne powiązanie sfery działań indywidualnych, nieformalnych z funkcjonowaniem sfery państwowej i jej agend. Te dwie sfery życia - publiczna (ale również państwowa) i prywatna - są w krajach europejskich ściśle ze sobą powiązane, dlatego niemożliwe jest, aby w każdej z nich, w sposób niezależny, inicjowane były procesy odpowiedzialne za wytwarzanie kapitału społecznego. Mimo że jest on domeną sfery działań obywatelskich, kontekst instytucjonalny odgrywa tutaj niezwykle ważną rolę.

Po drugie w analizowanych porządkach welfare states można zaobserwować spójny wzór zależności - poszczególne państwa należące do danego porządku są podobne pod względem zasobności kapitału społecznego. Wyróżniają się tutaj przede wszystkim kraje skandynawskie, reprezentujące najbardziej koherentny układ powiązań, następnie kraje z porządku korporacyjnego i Wielka Brytania, a dalej kraje śródziemnomorskie i postkomunistyczne. Relatywnie wysoki poziom kapitału społecznego w państwach socjaldemokratycznych może zaskakiwać, zwłaszcza że to właśnie te państwa służą za przykład najmocniej zorientowanych na realizację funkcji opiekuńczych. Funkcji, które dla wielu teoretyków i badaczy kapitału społecznego powinny raczej niwelować jego zasoby, a nie wzmacniać je. Ten pozorny paradoks próbuje się tłumaczyć specyfiką tych państw. Podkreśla się przede wszystkim wagę uniwersalnych programów społecznych, realizowanych w państwach skandynawskich, w przeciwieństwie do programów selektywnych, właściwych dla pozostałych państw opiekuńczych. Specyfika programów uniwersalnych polega na tym, że kierowane są one nie tylko do potrzebujących, ale do całej populacji lub też do łatwo wyodrębnianych segmentów, bez dociekania, czy beneficjenci mogliby płacić za siebie. Programy selektywne opierają się natomiast na procedurach 
weryfikacyjnych (needs testing) i trafiają do tych, którzy spełnią określone warunki. Prowadzi to do wywierania presji zarówno na pracownikach sektora publicznego, którzy często muszą interpretować przepisy w odniesieniu do specyficznych, indywidualnych sytuacji, jak i na starających się o wsparcie, od których wymaga się udowodnienia zasadności starań o pomoc (Kumlin i Rothstein 2005: 14-17). Taki mechanizm może prowadzić do poczucia deprywacji wśród obywateli, którzy uważają się za uprawnionych do otrzymania wsparcie socjalnego, ale takiej pomocy nie otrzymują. Ta deprywacja, co wydaje się oczywiste i znalazło odzwierciedlenie w danych, może skutkować kształtowaniem się negatywnych postaw wobec porządku instytucjonalnego. Co więcej, procedury selekcyjne sprzyjają powstawaniu nadużyć i działań korupcyjnych. Porównanie poziomu korupcji na podstawie indeksu percepcji korupcji (Transparency International 2010) w analizowanych krajach ujawnia, że w pierwszej dziesiątce najmniej skorumpowanych krajów świata znajdują się wszystkie państwa z porządku socjaldemokratycznego, a „ranking korupcyjny” w przypadku pozostałych jest zbieżny z rankingiem zasobności kapitału społecznego ${ }^{12}$. Satysfakcja instytucjonalna i zaufanie instytucjonalne $\mathrm{w}$ poszczególnych krajach są silnie skorelowane $\mathrm{z}$ wartością tego indeksu (odpowiednio $r$ Pearsona $=0,819$ i 0,737 dla $p<0,01$ ). Pomijając kwestię potencjalnych, negatywnych skutków oddziaływania instytucji państwa opiekuńczego (wysoki poziom fiskalizmu, zwiększający się udział wydatków budżetowych w PKB przyczyniający się do wzrostu deficytu budżetowego, rozrost biurokracji), warto odnotować, że jakość instytucji państwa (w tym instytucji państwa opiekuńczego) może mieć istotne znaczenie dla utrzymania (bardziej złożonym problemem wydaje się kwestia generowania) kapitału społecznego wśród obywateli. Jest to istotne zwłaszcza w tych krajach, w których instytucje społeczeństwa obywatelskiego nie zdążyły się w pełni ukształtować (jak w krajach postkomunistycznych) lub coraz mocniej muszą konkurować z podmiotami realizującymi politykę państwową w wymiarze społecznym czy ekonomicznym. Prezentowane dane wyraźnie pokazują, że kapitał społeczny w różnych układach welfare states podlega mechanizmowi dodatniego sprzężenia zwrotnego (virtuous circle). Jego wielkość zależy od sposobu zorganizowania tych porządków (programy uniwersalistyczne przeciw selektywnym), ich jakości (mierzonej poziomem korupcji i satysfakcją obywateli), wiarygodności i efektywności (testowanej poziomem zaufania) czy skłonności do koegzystowania z trzecim sektorem (dynamika rozwoju sfery publicznej, w tym aktywności obywatelskiej), ale także - co starał się wykazać w swoich badaniach Robert D. Putnam (1995) - nie pozostaje bez wpływu na sposób funkcjonowania tych instytucji.

\section{BIBLIOGRAFIA}

Boje, Thomas. 1996. Welfare state models in comparative research: do the models describe reality?, w: Bent Greve (ed.), Comparative welfare systems: the Scandinavian model in a period of change, Houndmills: Macmillan Press Ltd, s. 13-27.

12 Uśrednione wartości indeksu korupcji dla analizowanych porządków welfare state wynoszą odpowiednio: dla socjaldemokratycznego 8,9 (skala 0-10, gdzie 0 oznacza wysoki stopień korupcji, a 10 brak korupcji), korporacyjnego 7,8, anglosaskiego 7,7, śródziemnomorskiego 6,3 i potkomunistycznego 5,3. 
Bourdieu, Pierre i Loic J. D. Wacquant. 2001. Zaproszenie do socjologii refleksyjnej, Warszawa: Oficyna Naukowa.

Cohen, Jean L. i Andrew Arato. 1993. Civil Society and Political Theory. Cambridge, Mass: MIT Press.

Esping-Andersen, Gøsta. 1999. Social Foundations of Postindustrial Economies, New York: Oxford University Press.

Esping-Andersen, Gøsta. 2010. Trzy światy kapitalistycznego państwa dobrobytu, Warszawa: Difin.

European Social Survey Round 5 Data (2010). Data file edition 1.0. Norwegian Social Science Data Services, Norway - Data Archive and distributor of ESS data, dostęp online: http://ess.nsd.uib.no/ess/round5/ [6.10.2011].

Eurostat. 2011. Eurostat statistical book. Government finance statistics. Summary tables — 2/2011, dostęp online: http://epp.eurostat.ec.europa.eu/cache/ITY_OFFPUB/KSEK-11-002/EN/KS-EK-11-002-EN.PDF [20.10.2011].

Eurostat. 2012 Newsrelease euroindicators. 2/2012, dostęp online: http://appsso.eurostat. ec.europa.eu/nui/submitViewTableAction.do [7.03.2012].

Fukuyama, Francis. 2000. Social capital and civil society, IMF Working Paper.

Hagfors, Robert i Jouko Kajanoja. 2007. The Welfare State, Inequality and Social Capital, dostęp online: http://www.kent.ac.uk/scarr/events/Hagfors.pdf [18.10.2011].

Human Development Report 2010. $20^{\text {th }}$ Anniversary Edition. The Real Wealth of Nations: Pathways to Human Development, dostęp online: http://hdr.undp.org/en/media/HDR_2010_ EN_Complete_reprint.pdf [19.10.2011].

Ingen, Erik van i Tom van der Meer. 2011. Welfare state expenditure and inequalities in voluntary association participation, „Journal of European Social Policy”, vol. 21, no. 4, s. 302-322.

Księżopolski, Mirosław. 2004. Co dalej z polityka społeczna w Polsce? Od socjalistycznych gwarancji do paternalistyczno-rynkowej hybrydy, w: Marek Rymsza (red.), Reformy społeczne - bilans dekady, Warszawa: Instytut Spraw Publicznych, s. 193-222.

Kuhnle, Stein i Matti Alestalo. 2000. Introduction: growth, adjustments and survival of European welfare states, w: Stein Kuhnle (ed.), Survival of the European welfare state, London: Routledge, s. 3-18.

Kumlin, Staffan i Bo Rothstein. 2005. Making and Breaking Social Capital: the Impact of Welfare State Institutions, dostęp online: http://www.hks.harvard.edu/inequality/Seminar/ Papers/Rothstein2.pdf [18.10.2011].

Masłyk, Tomasz. 2010. Obywatel w społeczeństwie informacyjnym. Teoria i praktyka, Kraków: Zakład Wydawniczy NOMOS.

Miller, Chris. 2004. Producing Welfare, Houndmills, Basingstoke, Hampshire, New York: Palgrave Macmillan.

Oorschot, Wim van i Wil Arts. 2005. The social capital of European welfare states: the crowding out hypothesis revisited, „Journal of European Social Policy”, vol. 15, no. 1, s. 5-26. 
Kapitał społeczny w europejskich welfare states

Oorschot, Wim van, Wil Arts i John Gelissen. 2006. Social Capital in Europe Measurement and Social and Regional Distribution of a Multifaceted Phenomenon, „Acta Sociologica”, vol. 49, no. 2, s. 149-167.

Oorschot, Wim van, Wil Arts i Loek Halman. 2005. Welfare state effects on social capital and informal solidarity in the European Union: evidence from the 1999/2000 European Values Study, „Policy \& Politics”, vol. 33, no. 1, s. 33-54.

Polarczyk, Kazimierz. 2005. Budżet państwa w finansach publicznych. Polska na tle innych krajów, informacje BSiE, nr 1172, dostęp online: http://biurose.sejm.gov.pl/teksty_pdf_05/i-1172.pdf [30.10.2011].

Putnam, Robert D. 1995. Demokracja w działaniu. Tradycje obywatelskie we współczesnych Włoszech, Kraków-Warszawa: Wydawnictwo Znak, Fundacja im. S. Batorego.

Putnam, Robert D. 2008. Samotna gra w kręgle. Upadek i odrodzenie wspólnot lokalnych w Stanach Zjednoczonych, Warszawa: Wydawnictwa Akademickie i Profesjonalne.

Putnam, Robert D. i Kristin A. Goss. 2004. Introduction, w: Robert D. Putnam (ed.), Democracies in Flux: the Evolution of Social Capital in Contemporary Society, New York: Oxford University Press, s. 3-20.

Rogers, Michael T. 2001. The precursor to deliberative democracy, dostęp on line: http:// www.albany.edu/rockefeller/rockreview/issue1/011501.pdf [12.07.2066].

Rothstein, Bo. 2001. Social capital in the social democratic welfare state, „Politics \& Society", vol. 29, no. 2, s. 207-41.

Rothstein, Bo i Dietlind Stolle. 2003. Social Capital, Impartiality, and the Welfare State: an Institutional Approach, w: Marc Hooghe i Dietlind Stolle (eds.), Social Capital. Civil Society and Institutions in Comparative Perspective, New York: Palgrave Macmillan, s. 191-210.

Sartori, Giovanni. 1998. Teoria demokracji, Warszawa: Wydawnictwo Naukowe PWN.

Scheufele, Dietram i Dhavan V. Shah. 2000. Personality Strength and Social Capital. The Role of Dispositional and Informational Variables in the Production of Civic Participation, „Communication Research”, vol. 27, no. 2, s. 107-131.

Schwab, Klaus. 2011. The Global Competitiveness Report 2011-2012, dostęp online: http:// www3.weforum.org/docs/WEF_GCR_Report_2011-12.pdf [19.11.2011].

Swann, Abram de. 1988. In care of the state: State formation and collectivization of healthcare, education and welfare in Europe and Africa in the modern era, Oxford: Polity Press.

Szarfenberg, Ryszard. 2009. Modele polityki społecznej w teorii i praktyce, dostęp online: http://rszarf.ips.uw.edu.pl/pdf/modele_ps.pdf [30.10.2011].

Sztompka, Piotr. 2007. Zaufanie. Fundament społeczeństwa, Kraków: Wydawnictwo Znak.

Transparency International. 2010. Corruption Perception Index 2010 Results, dostęp online: http://www.transparency.org/policy_research/surveys_indices/cpi/2010/results [18.10.2011].

Wolfe, Alan. 1989. Whose Keeper? Social Science and Moral Obligation, Berkeley: University of California Press.

Woolcock, Michael i Deepa Narayan. 2000. Social Capital: Implications for Development Theory, „The World Bank Research Observer”, vol. 15, no. 2, s. 225-249. 


\section{SOCIAL CAPITAL IN EUROPEAN WELFARE STATES}

The crisis of public finances in European countries, makes the idea of the welfare state is exposed to particularly harsh criticism today. It is not limited to emphasize the lack of effectiveness of these institutions. Also emphasizes the negative impact of welfare state institutions to the third sector - reducing the areas of civic activity, and thus, elimination of natural resources to generate social capital. Referring to this problem, the objective of this article is to present the facts - the abundance of social capital at the disposal of citizens representing five types of welfare states: Anglo-Saxon, Continental Conservative, Social Democratic, Post-communist and Southern European. The measurement of social capital was carried out taking into account its three dimensions: trust (individual and institutional), civic activity (bonding and bridging capital) and satisfaction with life (individual and institutional). The empirical analysis is based on data from studies carried out in 2010 under the European Social Survey.

Key words: social capital, welfare state, trust, civic activity 